\title{
The isotopic climatic records in the Alleröd-Bølling- Younger Dryas and post-Younger Dryas events
}

\author{
Samuel Epstein \\ Division of Geological and Planetary Sciences, California Institute of Technology, Pasadena
}

\begin{abstract}
The combined isotopic records in the Greenland ice cores, in modern and ancient wood samples, and in marine foraminifera provide a climatic record for the Alleröd-Bølling-Younger Dryas and post-Younger Dryas Periods that is not compatible with the usual climatic interpretation of the ${ }^{2} \mathrm{H} /{ }^{1} \mathrm{H}$ ratios in the Greenland ice cores. For example, the Younger Dryas was not solely a North Atlantic event because evidence for it is also found in the ${ }^{2} \mathrm{H}^{1} \mathrm{H}$ record in wood samples which grew on the north slope of Alaska. The Younger Dryas was not necessarily a time of cooling over the ice caps. Moreover, it might have been a warming period in the temperate zones of the northem hemisphere continents. A better understanding of the climatic scenarios during these periods of time could be ascertained from additional isotopic data in plant remains which grew during these intervals and which cover a wider climatic range on the continents.
\end{abstract}

\section{Introduction}

The transition from the last Glacial Period to the present Interglacial Period is recorded in the isotopic composition of the Greenland deep ice cores (e.g., DYE 3) [Dansgaard et al., 1989]. This transition starts with a gradual increase in the $\delta \mathrm{D}$ values $\left[\delta \mathrm{D}=\left(\mathrm{R}_{\text {sample }} / \mathrm{R}_{\text {standard }}-1\right) \times 1000(\%), \mathrm{R}={ }^{2} \mathrm{H} /{ }^{1} \mathrm{H}\right.$, standard is Standard Mean Ocean Water (SMOW)], followed by a sharp increase of the $\delta D$ from -260 to $-230 \%$ (Figure 1a). This is referred to as the Alleröd-Bølling event. The AllerödBolling is followed by the Younger Dryas event, which is associated with a decrease of the $\delta \mathrm{D}$ value to $-285 \%$, followed by a rise to $-235 \%$ between 10.6 and $10.4 \mathrm{Kyr}$ B.P. This in turn is followed by a drop to $-255 \%$ and a rise to $-230 \%$, followed by the general trend toward the Interglacial Period. The Alleröd-Bølling is generally considered to be a warming event, and the Younger Dryas is a cooling event. Broecker et al. [Broecker et al., 1989; Broecker and Denton, 1990] attributed the cooling to a diversion of ice sheet meltwater from the Mississippi River to the St. Lawrence River drainage system [Broecker et al., 1989]. This diversion served to shut off the North Atlantic conveyor belt circulation system which currently supplies an enormous amount of heat to the atmosphere over the North Atlantic region. Consequently, "the Younger Dryas is primarily a North Atlantic and not a global event" [Broecker and Denton, 1990, pp. 54]. Enough stable isotope data now exist to form a basis for reexamining this interpretation as well as reconsidering the significance of the stable isotope records in ice cores and in samples of wood that grew during the late-glacial periods.

\section{Results and Discussion}

We analyzed the $\delta D$ of a series of 26 well-preserved ${ }^{14} \mathrm{C}$ dated plant remains from the north slope of Alaska (Figure

Copyright 1995 by the American Geophysical Union.

Paper number 95GB02741. 0886-6236/95/95GB-02741\$10.00 1b). Five of these samples were dated by Acceleration Mass Spectrometer (AMS) techniques. These samples were Salix (willow shrubs) collected in an area bordered by north latitude $69^{\circ} 38^{\prime}$ and $70^{\circ} 30^{\prime}$ and west longitude $151^{\circ} 36^{\prime}$ and $155^{\circ} 56^{\prime}$. Nonexchangeable hydrogen was extracted from the plant cellulose [Epstein et al., 1976]. Because both the ice and plants in effect record the isotopic composition of the ambient meteoric waters [Epstein et al., 1976; White et al., 1994], their $\delta \mathrm{D}$ records should be comparable. Preferential loss of cellulose in old wood due to aging does not affect the $\delta \mathrm{D}$ values of the original cellulose [Yapp and Epstein, 1977]. The negative plant $\delta \mathrm{D}$ values $(-217 \%$ to $-135 \%$, Figure 1$)$ indicate that the water used by these plants must have precipitated from air masses that experienced many cycles of isotopic fractionation prior to their arrival on the Alaskan north slope.

The Alaskan isotope record is plotted against ${ }^{14} \mathrm{C}$ age, and the DYE 3 ice core record [Dansgaard et al., 1989] is plotted against depth in Figure 1 . The coincidence of $\delta D$ maxima and minima and the similar ranges of the $\delta \mathrm{D}$ values for the Alaskan plant remains and the Greenland DYE 3 ice record suggests that the two records are reasonably synchronous.

As in the case of the ice record, the Alleröd-Bølling in the Alaskan wood record starts with a sharp increase of $+30 \%$ in the $\delta \mathrm{D}$ at approximately $12 \mathrm{Kyr}$ B.P., followed by a continuous decrease from -150 to $-220 \%$ correlated with the Younger Dryas event at approximately $10.5 \mathrm{Kyr}$ B.P. This is followed by a sharp rise to $-135 \%$, followed by a post-Younger Dryas oscillation extending over 1000 years, spanning a 30\%o range in $\delta \mathrm{D}$ values. The synchronous variations in the $\delta \mathrm{D}$ records in the ice core and in the willow shrubs are impressive and indicate that the Younger Dryas event is recorded in both isotope records and therefore was apparently not exclusively a North Atlantic event. In addition, the synchronous variations also indicate that the rate of the growth of the ice cap is relatively uniform for at least the period between 12 and $10 \mathrm{Kyr}$ B.P, suggesting a uniform temperature in this period of time. The smaller range in the $\delta \mathrm{D}$ values recorded in the ice core, as compared to that recorded in the wood samples from the north slope of Alaska, is likely due to some degree of homogeniza- 

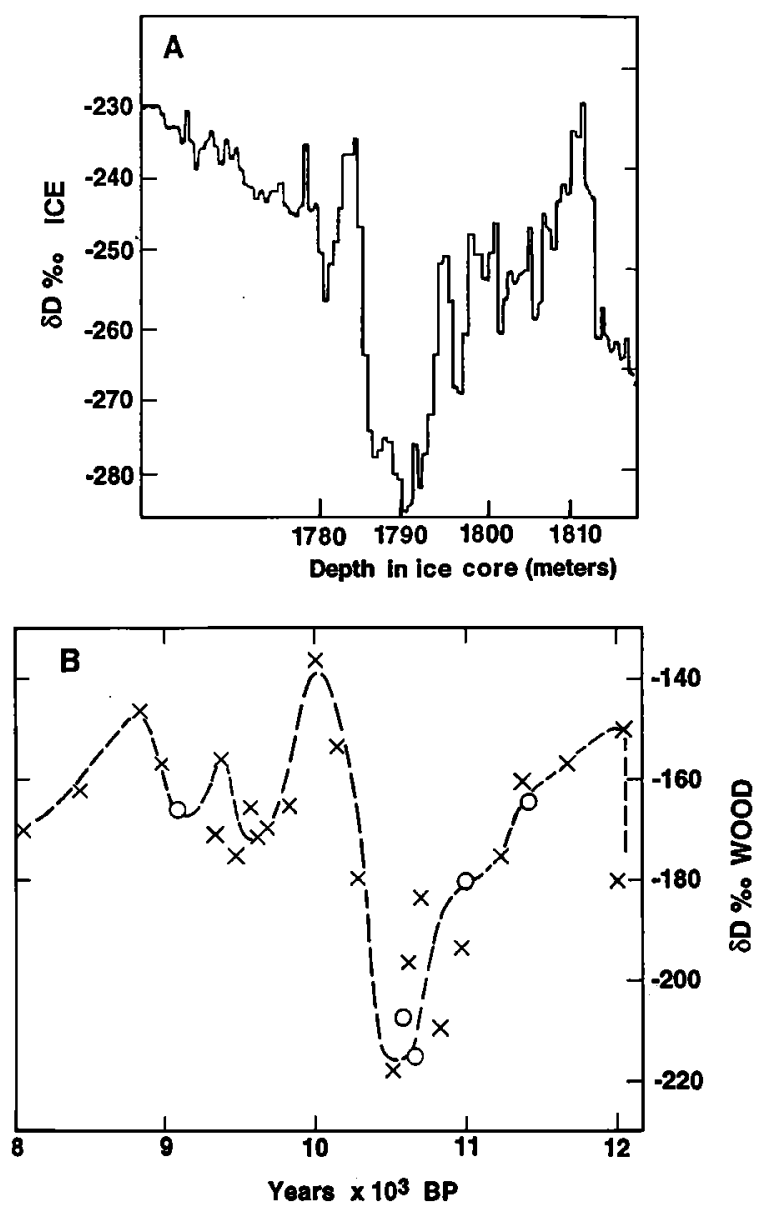

Figure 1. (a) The $\delta \mathrm{D}$ record of the ${ }^{14} \mathrm{C}$-dated willow shrub samples from the north slope of Alaska, as compared to (a) an exact copy of an enlarged version of the published DYE 3 ice core data from Greenland [Dansgaard et al., 1989]. The $\delta \mathrm{D}$ values of the ice cores are plotted against depth of the ice core samples on the ice cap. (b) The points marked with crosses have a suggested analytical uncertainty of \pm 160 years, whereas the open circles in Figure $1 \mathrm{~b}$ have been determined by the AMS technique with an error of \pm 80 years.

tion that must have taken place on the ice cap at this great depth in the core.

The good correlation between the $\delta \mathrm{D}$ records of the wood and the ice core between the period 12.3 to $10 \mathrm{Kyr}$ B.P. suggests similar variations in their respective marine sources and cooling histories of the air masses providing the moisture for these sites. It is difficult to imagine the distant Atlantic Ocean as the source of precipitation for the north slope of Alaska because the $\delta \mathrm{D}$ values of the north slope shrubs are systematically $-80 \%$ higher than those of the ice in the DYE 3 core in Greenland, which borders the Atlantic Ocean. It seems more reasonable to assume that the Pacific Ocean off the western North American continent was the dominant, ultimate source of the rain and snow that fell on the north slope during that time.

One of the unusual characteristics of the $\delta D$ record for the Greenland ice cap [Dansgaard et al., 1989] is the abrupt shift to lower values at approximately $10 \mathrm{Kyr}$, followed by a more gradual increase into the Holocene. This is usually explained as a rapid swing in air temperatures over the Greenland ice sheet. There is an alternative explanation for the existing isotope records for the Alleröd-Bølling-Younger Dryas and postYounger Dryas events.

An alternative scenario is suggested by the excess deuterium values ( $d=\delta \mathrm{D}-8 \delta^{18} \mathrm{O}$, where $d=$ excess deuterium) for the DYE 3 ice samples covering the transition from the Younger Dryas to the Preboreal [Dansgaard et al., 1989]. As suggested by Dansgaard et al. [1989], these data show that the marine source of moisture for the Younger Dryas in the polar regions was warmer than that for the Preboreal. They also suggested that this change was caused by a shift of a "dominating moisture source in the subtropical part of the Atlantic Ocean" [Dansgaard et al., 1989, pp. 533] and presumably by a warmer marine source of the moisture. Petit et al. [1991] show that the major effect on the magnitude of the excess deuterium in the Antarctic snow is directly related to the sea surface temperature of the source of the moisture.

The effect of surface ocean temperatures on the $\delta \mathrm{D}$ record of the ice caps is illustrated in Figure 2. This figure shows the Rayleigh-type curves, similar to those published by Yapp and Epstein [1977] that illustrate the relationship between isotopic composition and temperature of condensation for precipitation originating from ocean water with a $\delta \mathrm{D}$ of $0 \%$, but with different initial ocean surface temperatures $\left(20^{\circ}, 10^{\circ}\right.$ and $0^{\circ} \mathrm{C}$ ). These curves illustrate the effect of ocean surface temperature on the relationship between temperature and the isotopic composition in the ice caps. For example, arrow $A$ in Figure 2 shows that the $\delta \mathrm{D}$ record in the ice cap will remain constant at $-300 \%$, in spite of a cooling of $10^{\circ} \mathrm{C}$ on the ice cap, if at the same time the marine source of water feeding this ice cap cools by approximately $20^{\circ} \mathrm{C}$. On the other hand, arrow $B$ shows that an increase in $\delta D$ of approximately $130 \%$, normally indicating a warming trend, will be recorded on the ice cap if the overlying air temperature remains constant, while the temperature of the ocean's surface decreases from $20^{\circ}$ to $0^{\circ} \mathrm{C}$. It is the unique and transient temperature history of midlatitude ocean surfaces during the Allerơd-Bølling-Younger Dryas and post-Younger Dryas that could play an unusual but important role in determining the short-term isotopic variations on the ice caps at that time.

These $\delta \mathrm{D}$ values recorded in the ice cap depend on the difference in temperature between the air masses over the ice and the marine source of moisture. If simultaneous cooling of the ocean's surface and the atmosphere over the ice caps (DYE 3) is assumed to be responsible for a large decrease in $\delta D$ on the ice, certain circumstances have to exist. For example, assume an ocean temperature of $20^{\circ} \mathrm{C}$ and a temperature over the ice cap of $-8^{\circ} \mathrm{C}$. The cooling history of an air mass feeding the ice cap will result in a $\delta D$ value of $-200 \%$ for the snow of the ice cap, according to Figure 2. If the ocean temperature remains at $20^{\circ} \mathrm{C}$, but the temperature of the ice cap drops to $-15^{\circ} \mathrm{C}$, the $\delta \mathrm{D}$ of the snow on the ice cap will decrease to $-265 \%$, a change of $-65 \%$. However, if the ocean temperature decreases by $10^{\circ} \mathrm{C}$ and the temperature on the ice cap drops to $-15^{\circ} \mathrm{C}$, there should be no change in the $\delta \mathrm{D}$ of the snow on the ice cap. In order to cause the decrease in the $\delta \mathrm{D}$ of $-65 \%$ on the ice cap, the temperature on the ice cap would have to cool further to $-22^{\circ} \mathrm{C}$. The minimum $\delta \mathrm{D}$ value of the Younger Dryas in the DYE 3 core already approaches the $\delta \mathrm{D}$ value for the Glacial Period. It 


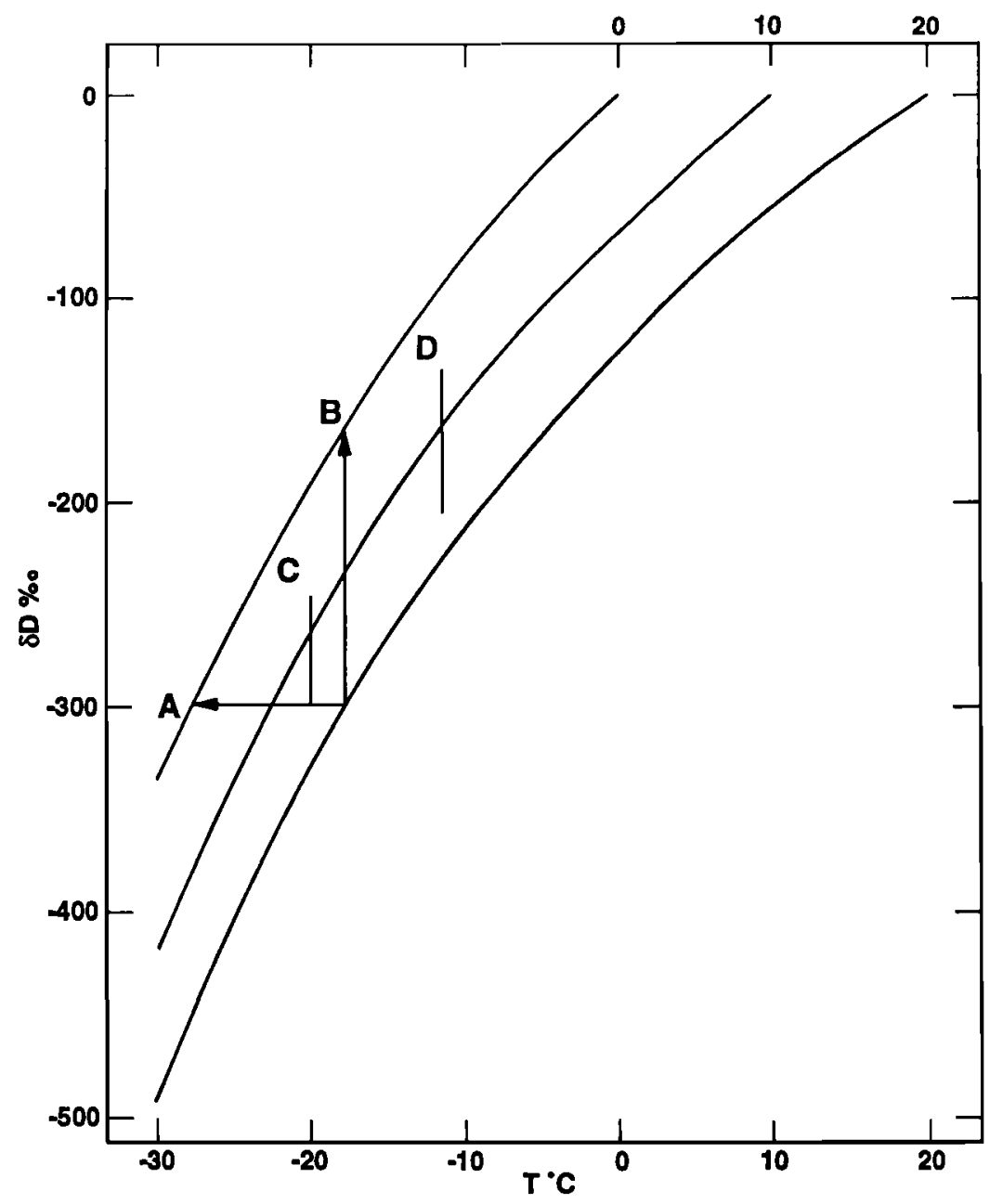

Figure 2. The relationships between the temperature and the isotopic composition of precipitation originating from an air mass which obtained its moisture from the surface of the ocean at three different ocean surface temperatures, $20^{\circ}, 10^{\circ}$ and $0^{\circ} \mathrm{C}$, were calculated using the Raleigh equation where the values of the isotopic fractionation factors were adjusted for the temperature of precipitation. Line A illustrates that the $\delta \mathrm{D}$ of the snow for the ice cap will remain constant if both the temperature of the air mass over the ice cap and the temperature of the surface of the ocean decrease simultaneously. Line $B$ illustrates the $\delta \mathrm{D}$ record of the ice at a specific location at a constant temperature, when the temperature of the marine source of water changes from $20^{\circ}$ to $0^{\circ} \mathrm{C}$. Line $\mathrm{C}$ is the range of the $\delta \mathrm{D}$ for the DYE 3 ice core, assuming that the range $15^{\circ}-8^{\circ} \mathrm{C}$ is entirely due to the temperature change of the ocean surface. Line $D$ is similar to Line $C$ but covers the $\delta D$ range for the samples from the north slope of Alaska.

seems unlikely that the temperature of the Younger Dryas of the ice cap would be lower than temperature during the Glacial Period.

In order to calculate a priori the $\delta \mathrm{D}$ of the ice caps from presumed changes in the ocean temperature, some initial conditions must be specified. A temperature of $15^{\circ} \mathrm{C}$ for the ocean surface was assigned to a specific $\delta \mathrm{D}$ value of $-300 \%$ in the ice core. This will define a constant temperature of $-20^{\circ} \mathrm{C}$ over the ice cap. If the $\delta D$ of the ice is increasing as time progresses from 12.3 Kyr B.P. toward younger ages while air temperature over the ice remains fixed at $-20^{\circ} \mathrm{C}$, the surface ocean temperature would decrease from $15^{\circ} \mathrm{C}$ to $8^{\circ} \mathrm{C}$. The broken line in Figure 3a was calculated from line $\mathrm{C}$ in Figure 2 for a decrease in ocean water temperature from $15^{\circ}$ to $8^{\circ} \mathrm{C}$ at $12.3 \mathrm{Kyr} \mathrm{B} . \mathrm{P}$., followed by an increase in ocean water temperature of $-7^{\circ} \mathrm{C}$ to $10.5 \mathrm{Kyr}$ B.P., then followed by a decrease in ocean water temperature of $\sim 6^{\circ} \mathrm{C}$ to $10 \mathrm{Kyr}$ B.P. This whole scenario from 12.3 to $10 \mathrm{Kyr}$ B.P. could be accomplished by respective injection of cold water to the ocean surface followed by the incorporation of the cold surface water into the dominant preinjection water whose temperature was $15^{\circ} \mathrm{C}$, and then followed by another injection of cold water to the ocean surface.

Figure 2 can also be applied to the data from the north slope of Alaska. The only difference involves the assignment of a constant temperature of this source of water used for the plant growth. The minimum $\delta \mathrm{D}$ of this water is $-215 \%$ and the temperature range for the ocean is between $17^{\circ}$ and $8^{\circ} \mathrm{C}$, as previously assigned. As a consequence, the temperature of the ice 
cap in Alaska which provides the water for the plant growth would be $-12^{\circ} \mathrm{C}$. Line $\mathrm{D}$ in Figure 2 could be used to define the range of the $\delta \mathrm{D}$ record from the north slope of Alaska.

The temperature of the oceans is a major factor affecting the isotopic composition of rain and snow and therefore the $\delta D$ records in the ice caps and wood samples [Yapp and Epstein, 1977]. Fairbanks [1989] (Figures 3 and 4) and Bard et al. [1987] studied the implication of the injection of meltwater to the surface of the ocean and the ocean temperature during the Alleröd-Bølling-Younger Dryas periods. Here we attempt to determine if we can create the type of calculated $\delta D$ record shown in Figure 3a as a model for the DYE 3 ice core by using a completely different source of information, namely the $\delta^{18} \mathrm{O}$ record reported by Bard et al. [1987] for the pelagic foraminifera in a sedimentary core taken off the coast of Portugal. We plot the $\delta^{18} \mathrm{O}$ of Bard et al. [1987] (Figure 4a) as a relationship between the $\delta^{18} \mathrm{O}$ and ${ }^{14} \mathrm{C}$ dates, rather than the variation of the $\delta^{18} \mathrm{O}$ record with depth in the core. The foraminifera $\delta^{18} \mathrm{O}$ values before $10.5 \mathrm{Kyr}$ (Figure 4a) appear to vary synchronously with the $\delta \mathrm{D}$ records of the DYE 3 ice core from Greenland and the wood remains from the north slope of Alaska (Figure 1). Under normal conditions of a relatively constant $\delta^{18} \mathrm{O}$ of ocean water, a lower $\delta^{18} \mathrm{O}$ in the marine car-

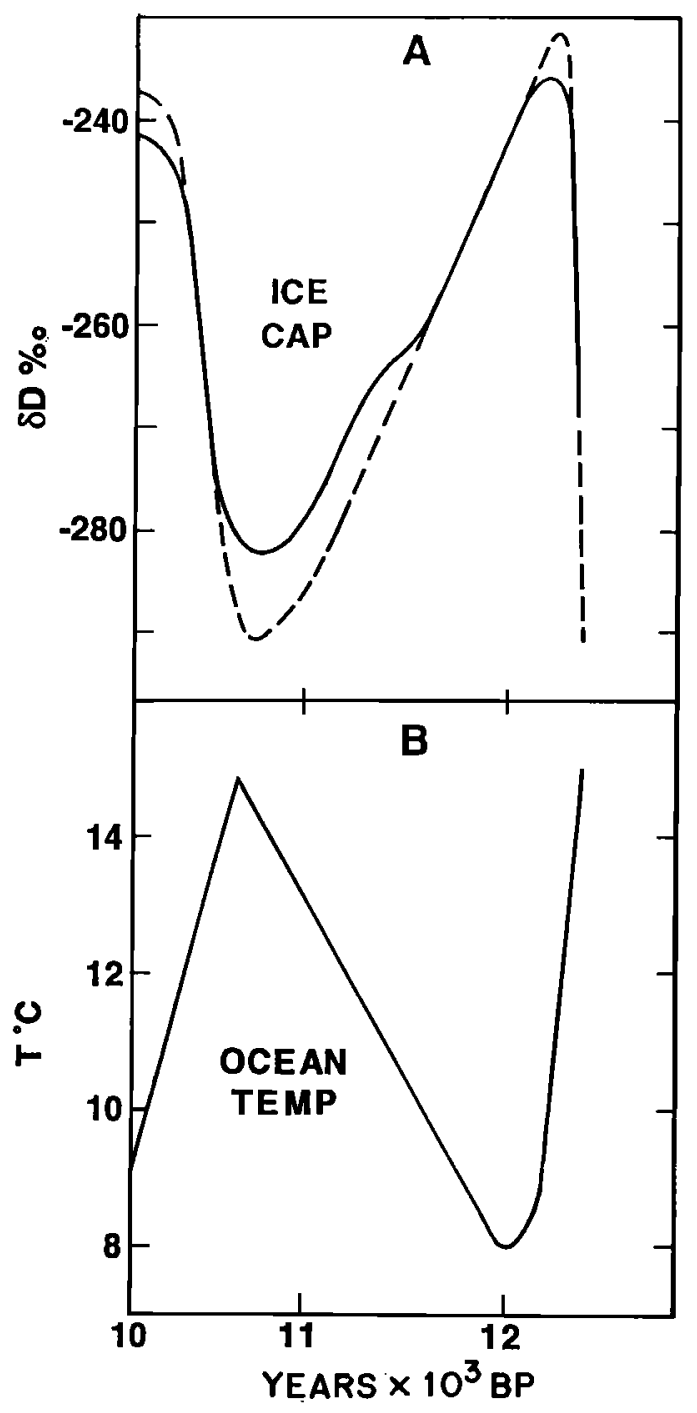

bonates reflects warmer ocean temperatures, consistent with the conventional interpretation of the Greenland data that the Alleröd-Bølling Period represents a warming temperature. A rapid rise in ocean surface temperatures at about $12.3 \mathrm{Kyr}$ was inferred from "a paleontological transfer function" [Bard et al., 1987, pp. 792], as well as the $\delta^{18} \mathrm{O}$ values for the foraminifera. However, it is difficult to imagine a rise of about $7^{\circ} \mathrm{C}$ in the temperature of the ocean in 200 years, from 12,460 to $12,260{ }^{14} \mathrm{C}$ years B.P. [Bard et al., 1987], at the time when global sea level apparently rose by some 24 meters as a consequence of a rapid influx of glacial meltwater [Fairbanks, 1989]. The physical basis of Fairbanks' results seems to be sound, and his conclusions about times and rates of sea level rise are accepted here as valid in the subsequent discussion.

If a rapid variation of the meltwater input into the North Atlantic during the glacial-interglacial transition (Figures. 1 and $4 \mathrm{a}$ ) is the common cause of the rapid and synchronous isotopic variations in the Greenland DYE 3 ice core [Dansgaard et al., 1989] and in the planktonic foraminifera off Portugal [Bard et al., 1987] (see Figures. 2 and 3a), the following can reconcile the isotopic variations with material balance constraints. If a mixture of meltwater and cold surface ocean water from the North Atlantic was injected into the surface ocean water off Portugal at $\sim 12.4 \mathrm{Kyr}$ B.P. (Figure $4 \mathrm{a}$ ), it would have produced a new mixture. The cold water mixture from the North Atlantic $\left(-0^{\circ} \mathrm{C}\right)$ could have had lower $\delta^{18} \mathrm{O}$ values, because of its meltwater component. The normally warmer $\left(15^{\circ} \mathrm{C}\right)$ [CLIMAP Project Members, 1976] and higher $\delta^{18} \mathrm{O}(-2.0 \%)$ surface ocean waters in the midlatitudes would thus have been isotopically and thermally modified by the introduction of the North Atlantic water. A value of $2.0 \%$ is probably a reasonable estimate of "normal" lower latitude surface ocean water $\delta^{18} \mathrm{O}$ value, because of the ${ }^{18} \mathrm{O}$-depleted ice caps during the Glacial Period as well as the normal excess evaporation of surface water at those latitudes [Sverdrup et al., 1942]. Lower latitude surface ocean waters modified by the mixing would markedly affect the calculated temperature recorded in the $\delta^{18} \mathrm{O}$ of the Portuguese foraminifera. The effect of such mixing on the midlatitude surface oceans would have been to lower their temperatures from $15^{\circ}$ to $8^{\circ} \mathrm{C}$ and $\delta^{18} \mathrm{O}$ values from 2.0 to $-0.6 \%$. We have basically selected the combination of temperature and the isotopic composition of water mixtures which

Figure 3. (a) The $\delta \mathrm{D}$ record measured in the DYE 3 ice core sample (solid line) compared to that calculated for specified variations of the surface ocean temperature (broken line) of the source of the moisture feeding the ice caps. (b) The presumed surface ocean temperature in the source region is shown. The temperature of the ice cap and the $\delta \mathrm{D}$ of the ocean surface were assumed to be constant at $-20^{\circ} \mathrm{C}$ and $0 \%$, respectively, for the generated record. The difference in the curves of Figure $3 \mathrm{a}$ is due to the fact that at $12.3 \mathrm{Kyr}$ B.P., the $\delta^{18} \mathrm{O}$ of the ocean which yielded the moisture that actually accumulated in the ice core (solid line) was probably about $2.0 \%$, and not $0 \%$, as assumed for the calculated line. This explains why the solid line begins at $12.3 \mathrm{Kyr}$ B.P., with a $\delta \mathrm{D}$ value $20 \%$ o higher than that of the broken line at $12.3 \mathrm{Kyr}$ B.P. The measured $\delta \mathrm{D}$ value that is lower by $5 \%$ than that calculated at $12 \mathrm{Kyr}$ B.P. is assumed to be a consequence of the addition of cold water with a $\delta^{18} \mathrm{O}$ value of approximately $-3.5 \%$ which changed the $\delta^{18} \mathrm{O}$ of the surface ocean water from $2.0 \%$ at $12.3 \mathrm{Kyr}$ B.P. to $-0.6 \%$ at $12 \mathrm{Kyr}$ B.P. (see text). 


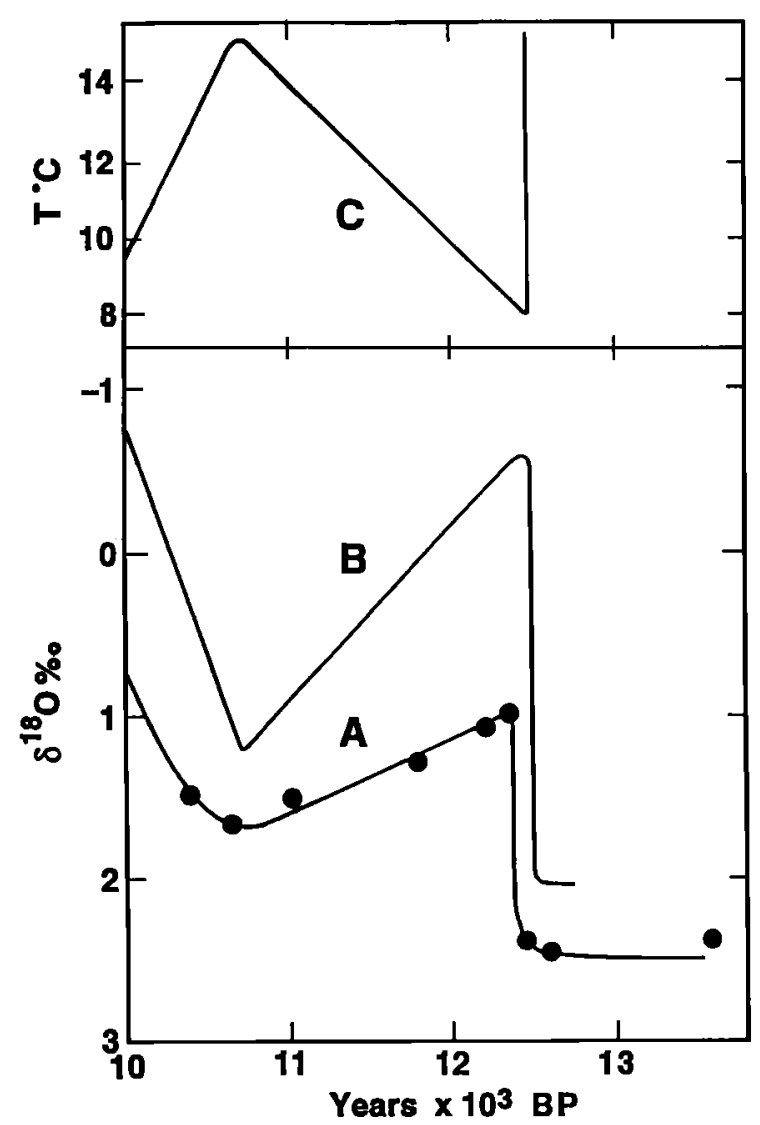

Figure 4. Curve $\mathrm{C}$ represents the temperature of the surface ocean shown in Figure $3 \mathrm{~b}$, which matches quite well the temperature record calculated from the difference between the $\delta^{18} \mathrm{O}$ record of the foraminifera (curve $A$ ) and the $\delta^{18} \mathrm{O}$ of the water (curve B) off the coast of Portugal. It was assumed that the cooling of this surface ocean water and increase in its $\delta^{18} \mathrm{O}$ at $12.3 \mathrm{Kyr}$ B.P. resulted from the initial addition of cold oceanic surface water from higher latitudes with a $\delta^{18} \mathrm{O}$ of $-3.5 \%$ and a temperature of $0^{\circ} \mathrm{C}$. The subsequent increase in the $\delta^{18} \mathrm{O}$ was due to the shutoff of the cold high-latitude water and remixing of the modified Portuguese water with ocean water that had an initial $\delta^{18} \mathrm{O}$ of $2.0 \%$ and temperature of $15^{\circ} \mathrm{C}$. This remixing is thought to have yielded Portuguese surface ocean water with a $\delta^{18} \mathrm{O}$ of $1.2 \%$ and a temperature of about $15^{\circ} \mathrm{C}$.

mixed with the warm surface water off Portugal to conform to the previously presented model (Figure 3a) which accounts for the $\delta D$ record in the DYE 3 ice core and in the wood which grew in the north slope of Alaska. The same combination will also conform with our interpretation of the ocean surface temperature recorded by the $\delta^{18} \mathrm{O}$ record in the pelagic foraminifera [Bard et al., 1987]. A variety of mixtures could be injected into the ocean water off the coast of Portugal which would meet these conditions.

Because the specific heat of this injected water and the ocean water are very similar, the general material balance equation applies to this case:

For temperature: $\quad 15.0(X)+T_{o}(Y)=8^{\circ} \mathrm{C}$

For isotopic of ocean water: $2.0(X)+\delta^{18} \mathrm{O}(Y)=-0.6 \%$

where $X$ and $Y$ are, respectively, the fractions of the contribution of the water off the coast of Portugal and of the cold water of temperature $T_{o}$ injected into that location. $X+Y=1, T_{o}<$ $15^{\circ} \mathrm{C}$, and $\delta^{18} \mathrm{O}<-0.6 \%$. For $T_{o}=0^{\circ} \mathrm{C}$ and $\delta^{18} \mathrm{O}$ of cold water equals $-3.5 \%, X=0.47$ and $Y=0.53$. For $T_{o}=4.3^{\circ} \mathrm{C}$ and $\delta^{18} \mathrm{O}$ of cold water equals $-2.0 \%, X=0.35$ and $Y=0.65$. In principle, a large variety of mixtures of the two sources of water can be used to define the temperature of $8^{\circ} \mathrm{C}$ and the $\delta^{18} \mathrm{O}$ of $-0.6 \%$.

We have defined reasonable conditions whereby a decrease of temperature of $7^{\circ} \mathrm{C}$ off Portugal at $12.4 \mathrm{Kyr}$ B.P. could be recorded by the foraminifera whose $\delta^{18} \mathrm{O}$ actually changed from 2.4 to $1.0 \%$, a $\delta^{18} \mathrm{O}$ change which would normally be associated with a rise in temperature. Following this cooling event at $12.4 \mathrm{Kyr}$ B.P., a cutoff of the cold high-latitude water would allow the temperature of the ocean surface off Portugal to return fairly close to its presumed original temperature of approximately $15^{\circ} \mathrm{C}$ (Figure 3c) and the surface water $\delta^{18} \mathrm{O}$ to increase (Figure 3b). The $\delta^{18} \mathrm{O}$ of the foraminifera increases from $+1.0 \%$ at $-12.3 \mathrm{Kyr}$ B.P. to $+1.7 \%$ at $10.6 \mathrm{Kyr}$ B.P. (Figure 3a). As deeper more ${ }^{18} \mathrm{O}$-rich water mixed with the surface water, the $\delta^{18} \mathrm{O}$ of the water has to increase from -0.6 to $+1.2 \%$ to be consistent with the model and the hypothesized rise in temperature. The second relatively rapid addition of cold water began at $-10.5 \mathrm{Kyr}$ B.P. [Fairbanks, 1989]. The $\delta^{18} \mathrm{O}$ of the foraminifera at this time decreased from 1.7 to $0.8 \%$ at about $10 \mathrm{Kyr}$ B.P. For a value of $\delta^{18} \mathrm{O}=-3.5 \%$ and a temperature $=0^{\circ} \mathrm{C}$ for the cold water injected at $10.5 \mathrm{Kyr}$ B.P., added to water with a $\delta^{18} \mathrm{O}$ value of $1.2 \%$ (Figure $4 \mathrm{~b}$ ) and a temperature of $15^{\circ} \mathrm{C}$ (Figure $4 \mathrm{c}$ ), this second addition of cold meltwater would have lowered the surface ocean water temperature off the coast of Portugal to about $9^{\circ}$ or $10^{\circ} \mathrm{C}$ and the $\delta^{18} \mathrm{O}$ value of ocean water to $-0.8 \%$ corresponding to a foraminifera $\delta^{18} \mathrm{O}$ of $+0.7 \%$.

A comparison between Figures 3 and 4 illustrates that the ocean temperatures used to calculate the $\delta \mathrm{D}$ of the ice cores are similar to those calculated from the foraminifera data, if the foregoing assumptions are made regarding the effect of cold water injection into the area of the foraminifera growth. The gradual warming over the ice cap due to the combined forcing of the Milankovitch effects could cause a gradual increase in the $\delta \mathrm{D}$ of the ice cap during the glacial-interglacial transition. The large Allerőd-Bølling and Younger Dryas $\delta \mathrm{D}$ oscillations in the ice cap record appear as extraordinary transient phenomena. This paper proposes that meltwater-induced rapid changes in ocean surface temperatures at the moisture source can account for the ice cap $\delta \mathrm{D}$ oscillations. The similar $\delta \mathrm{D}$ record from the Alaskan samples could be in response to similar variations in Pacific ocean temperature.

One of the apparent inconsistencies in the curves labeled "ice cap" in Figure 3a is the difference between the calculated $\delta \mathrm{D}$ record obtained from the temperatures of the ocean (broken line) and that measured in the Greenland ice cap (solid line) for the change at $\sim 12.4 \mathrm{Kyr}$ B.P. The model ocean water temperature decrease of $7^{\circ} \mathrm{C}$ at that time yields a calculated ice core $\delta \mathrm{D}$ increase of $50 \%$, but the corresponding measured increase in $\delta \mathrm{D}$ on the ice cap is only $29 \%$. However, these apparently inconsistent results actually reinforce our scenario because the difference in the $\delta D$ records is what is expected at that time due to the proposed changes in the $\delta D$ values of the ocean surface waters. Associated with an ocean temperature drop at $12.4 \mathrm{Kyr}$ B.P. is the decrease of $2.6 \%$ in the $\delta^{18} \mathrm{O}$ of the ocean surface water (equivalent to $21 \%$ in the $\delta D$ ) (curve $B$ in Figure 4). 
Since the calculated curve of Figure $3 \mathrm{a}$ is based on the assumption that the $\delta \mathrm{D}$ of the ocean water is $0 \%$, the fact that the measured $\delta D$ is $21 \%$ higher than the calculated $\delta D$ is due to a $\delta \mathrm{D}$ value of $+21 \%$ o $\left(8 \times 2.6 \delta^{18} \mathrm{O}\right)$ for the ocean prior to 12.4 Kyr B.P. For that $\delta D$ value of surface ocean water, a decrease in surface ocean water temperature of $7^{\circ} \mathrm{C}$ would cause a calculated rise in the $\delta \mathrm{D}$ on the ice cap from -270 to $-220 \%$. However, since the cooling of the ocean's surface is proposed to have been caused by the injection of low- $\delta D$ cold water which resulted in a decrease of the $\delta D$ of the Portuguese surface ocean water of about $21 \%$, the $\delta D$ of the ice on the ice cap would also decrease by about $20 \%$, resulting in the observed SD value of about $-240 \%$, instead of $-220 \%$.

Up to this point, we have confined our discussions to the isotope records between 12.4 and $10 \mathrm{Kyr}$ B.P. This was due to the absence of convincing evidence that rapid injection of cold water, followed by a cutoff of the cold water, occurred during the period of 10 to $8.8 \mathrm{Kyr}$ B.P. We wish to include the isotope data to suggest further investigations regarding the isotopic and other climatic records for this period (Figure 5).

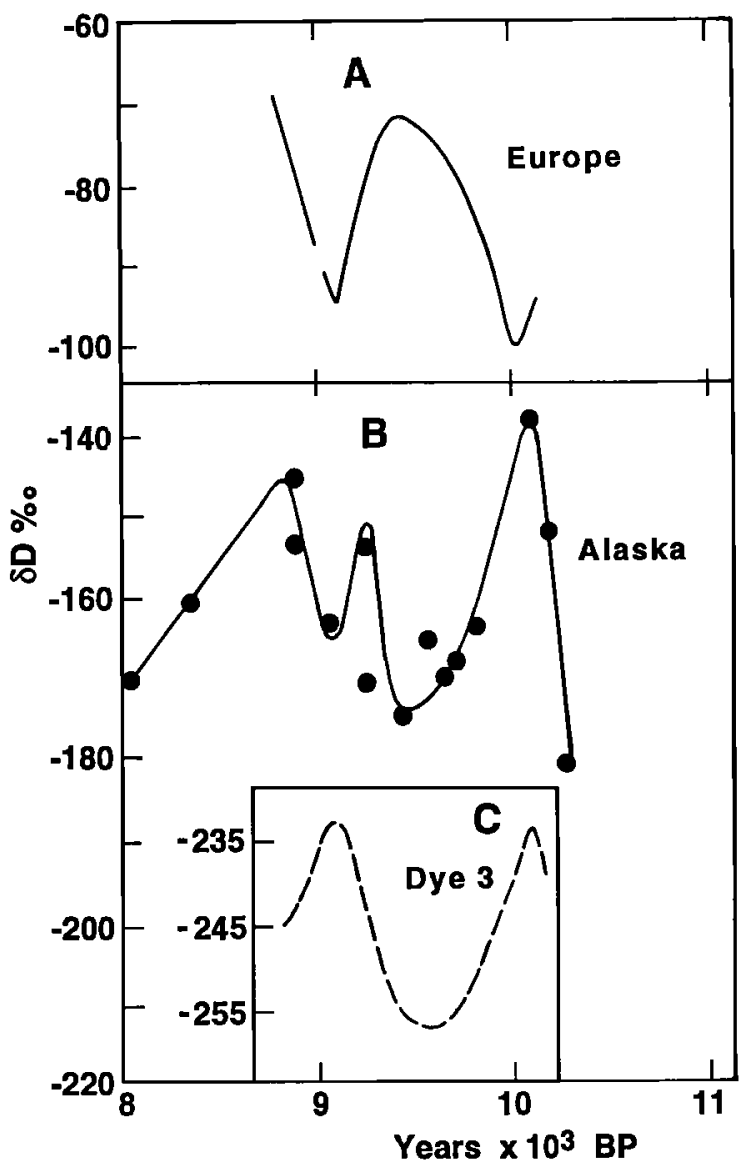

Figure 5. Comparison of the $\delta D$ records of the ${ }^{14} \mathrm{C}$-dated Alaskan wood samples, the ${ }^{14} \mathrm{C}$-dated German pine samples, and the DYE 3 ice core samples between the period of 10 to 8.8 $\mathrm{Kyr}$ B.P. The ${ }^{14} \mathrm{C}$ dates for the German pine samples were estimated from the relationship between the absolute and the ${ }^{14} \mathrm{C}$ dates by Bard et al. [1990], using the Becker absolute tree ring chronology [Becker et al., 1991]. The $\delta D$ record for the DYE 3 ice core samples is presented in this figure only for the purpose of the $\delta \mathrm{D}$ comparison with that of the post-Younger Dryas event recorded in the Alaskan and German data.
A comparison of the $\delta \mathrm{D}$ records of German pine trees [Becker et al., 1991] with the Alaskan wood samples and the DYE 3 ice core shows a relationship dissimilar to that observed for the $\delta \mathrm{D}$ values of the wood from the polar region and the ice core samples. $A \delta D$ increase of $30 \%$ in the pine trees is correlated with a decrease in $\delta D$ of $30 \%$ for the Alaskan record, and a 25\%o decrease for the DYE 3 record. By this time the $\delta \mathrm{D}$ or $\delta^{18} \mathrm{O}$ of the oceans were already quite similar to modern values, and Becker et al. [1991] present evidence that their $\delta \mathrm{D}$ values are directly related to continental warming.

As we have already pointed out, a warming ocean surface could result in a corresponding lowering of the $\delta \mathrm{D}$ values in the polar regions as the cold water injection is shut off at -10 Kyr B.P. The question then is, was there a small injection of cold water at $-9.5 \mathrm{Kyr}$ B.P., as indicated by the rise in $\delta \mathrm{D}$ at this point in time in the Alaskan wood samples and in the DYE 3 ice core? Such an injection of cold polar water was not obvious in the data of Fairbanks [Fairbanks, 1989] or in the $\delta^{18} \mathrm{O}$ data for the pelagic foraminifera reported by Bard et al. [1987]. However, in the case of the foraminifera data, there are only two data points for the $\delta^{18} \mathrm{O}$ values for the time period 10 to $8.8 \mathrm{Kyr}$ B.P. It would be interesting to invest additional effort in obtaining more detailed records for ${ }^{14} \mathrm{C}$-dated tree samples and foraminifera for possible identification of the presence of periodic injections of cold meltwater from the ice caps.

Although there might be small magnitude, short-term fluctuations in the temperature of the surface ocean waters, over the longer term the surface ocean temperatures may remain stable (within a few degrees) or change gradually in response to worldwide climate changes. At such times, corresponding temperature changes will occur in the ice caps as well. Consequently, the $\delta \mathrm{D}$ records in the ice cap should usually reflect primarily the air temperature over the ice. This emphasizes the point that the model presented here concerning surface ocean temperatures is for the special circumstances associated with a glacial to interglacial climatic transition as represented by the Bølling-Younger Dryas and post-Younger Dryas oscillations. On the other hand, if the ice records contain relatively rapid fluctuations in their isotopic compositions, it is relevant to consider the possible role that ocean temperatures might play in determining these records. It is obviously important to complement this isotopic record with temperature-sensitive $\delta \mathrm{D}$ records of different materials found at other locations on the continents. These will be critical to the understanding of the climate dynamics responsible for the history of the climate on Earth. The impact of the isotopic records of the few nonglacial sources used in this paper illustrates how important these records can be in providing information about past climates.

\section{Summary}

In spite of the uncertainties associated with determining the exact simultaneity of events recorded in these different, widely separated systems, the temporal correspondence of the large isotopic variations between -10 and $12.5 \mathrm{Kyr}$ B.P. is striking and has important implications. The $\delta \mathrm{D}$ data on the wood samples from the north slope of Alaska suggest that the Alleröd-Bølling and Younger Dryas were widespread events in 
the northern hemisphere. The combination of isotope data from the Alaskan wood, the Greenland ice cap and pelagic foraminifera with sea level data from Barbados suggests that the Alleröd-Bølling event was initiated by rapid cooling, and the Younger Dryas event by a rapid warming in the midlatitude North Atlantic Ocean and probably in part of the North Pacific Ocean. These proposed temperature changes could be due to rapid addition and subsequent shutoff of meltwater-augmented, high-latitude surface ocean waters. Consequently, the large, rapid isotopic oscillations that were recorded on the north slope of Alaska and in the ice caps during the GlacialInterglacial transition need not necessarily be associated with temperature variations at these locations. Isotope analyses of accurately ${ }^{14} \mathrm{C}$-dated wood samples from various countries would provide critical information about the climatic history of these areas during the Alleröd-Bølling-Younger Dryas and post-Younger Dryas events. Outside of the time span covering these events, the general ice core isotopic record for the transition between the Glacial and Interglacial periods could be due mainly to warming of the air over the ice caps, if the temperature of the ocean source for the moisture feeding the ice caps remained relatively constant.

Acknowledgments. It is a pleasure to acknowledge David Carter, USGS Alaska Branch, for providing the ${ }^{14} \mathrm{C}$-dated samples from the north slope of Alaska and for his helpful remarks on earlier versions of this manuscript. Crayton Yapp made critical contributions to this manuscript with his cogent and greatly appreciated remarks. We also acknowledge the technical assistance of Eleanor Dent, Xiahong Feng, Xiaomei Xu, and Meg Garstang. This research was supported by NSF ATM9219891 to Samuel Epstein.

\section{References}

Bard, E., M. Arnold, P. Maurice, J. Duprat, J. Moyes, and J.-C. Duplessy, Retreat velocity of the North Atlantic polar front during the last deglaciation determined by ${ }^{14} \mathrm{C}$ accelerator mass spectrometry, Nature, 328, 791-794, 1987.
Bard, E., B. Hamelin, R.G. Fairbanks, and A. Zindler, Calibration of the ${ }^{14} \mathrm{C}$ timescale over the past 30,000 years using mass spectrometric UTh ages from Barbados corals, Nature, 345, 405-410, 1990.

Becker, B., B. Kromer, and P. Trimborn, A stable-isotope tree-ring timescale of the Late Glacial/Holocene boundary, Nature, 353, 647649, 1991.

Broecker, W.S., and G.H. Denton, What drives glacial cycles?, Sci. Am. $262(1), 48-56,1990$.

Broecker, W.S., J.P. Kennett, B.P. Flower, J.T. Teller, S. Trumbore, G. Bonani, and W. Wolfli, Routing of meltwater from the Laurentide Ice Sheet during the Younger Dryas cold episode, Nature, 341, 318$321,1989$.

Climate: Long-Range Investigation, Mapping, and Prediction (CLIMAP) Project Members, The surface of the Ice-Age Earth, Science, 191, 1131-1137, 1976.

Dansgaard, W., J.W.C. White, and S.J. Johnsen, The abrupt termination of the Younger Dryas climate event, Nature, 339, 532-534, 1989.

Epstein, S.; C.J. Yapp, and J.H. Hall, The determination of the D/H ratio of non-exchangeable hydrogen in cellulose extracted from aquatic and land plants, Earth Planet. Sci. Lett., 30, 241-251, 1976.

Fairbanks, R.G., A 17,000-year glacio-eustatic sea level record: Influence of glacial melting rates on the Younger Dryas event and deep-ocean circulation, Nature, 342, 637-642, 1989.

Petit, J.R., J.W.C. White, N.W. Young, J. Jouzel, and Y.S. Korotkevich, Deuterium excess in recent Antarctic snow, J. Geophys. Res., 96, 5113-5122, 1991.

Sverdup, H.U., M.W. Johnson, and R.H. Fleming, The Ocean, Their Physics, Chemistry and General Biology, Prentice-Hall, Inc., New York, 1942.

White, J.W.C., J.R. Lawrence, and W.S. Broecker, Modeling and interpreting D/H ratios in tree rings: A test case of white pine in the northeastern United States, Geochim. Cosmochim. Acta, 58, 851-862, 1994.

Yapp, C.J., and S. Epstein, Climatic implications of D/H ratios of meteoric water over North America (9500-22,000 B.P.) as inferred from ancient wood cellulose C-H hydrogen. Earth Planet. Sci. Lett., 34, 333-350, 1977.

S. Epstein, Division of Geological and Planetary Sciences, 170-25, California Institute of Technology, Pasadena, CA. 91125. (e-mail: epstein@arms.gps.caltech.edu)

(Received July 23, 1995; revised August 30, 1995; accepted September 5, 1995.) 